\title{
Weronika Plińska
}

\author{
Pedagogical University of Cracow
}

\section{Crafting the Self Through Participation in Community Art Projects}

\section{Rzeźbienie siebie poprzez uczestnictwo w projektach sztuki wśród społeczności lokalnych}

\begin{abstract}
In this article I will recall some of the arguments revising the nature of the relationship between individual and society. I will focus on the notion of personhood and discuss how it is being crafted through one's participation in a community art project. I will explain what kind of values are transmitted under such circumstances. I will also discuss some of the practices of "dealing with objections" ${ }^{\prime 1}$ as a way of managing the project.

Here I will draw from my own fieldwork experience. As a part of my PhD research project I was personally involved in working in community art projects done in the rural areas of central Poland (2008-2010).

\section{KEYWORDS:}

community art, cultural animation, anthropology of art, anthropology of development, personhood, apprenticeship, cultural policy, ethnography

${ }^{1}$ D. Mosse, Anti-social anthropology? Objectivity, objection and the ethnography of public policy and professional communities, "Journal of the Royal Anthropological Institute", 4/2006, pp. 935-956.
\end{abstract}

\begin{abstract}
ABSTRAKT
W artykule przywołam kilka wątków toczącej się obecnie w antropologii dyskusji, której celem jest próba uchwycenia na nowo istoty relacji pomiędzy jednostką a społeczeństwem. Skupię się na pojęciu 'osoby' i przedstawię to, w jaki sposób pewien jej model jest wytwarzany (formowany, rzeźbiony) za sprawą uczestnictwa w projektach „sztuki wśród społeczności lokalnych" (animacja kultury, community arts). Zastanowię się nad tym, jakiego rodzaju wartości przekazywane są $w$ ramach działania animacyjnego poprzez zawiązywane w nim relacje. Zwrócę również uwagę na praktyki „radzenia sobie ze sprzeciwem" obecne w zarządzaniu projektem animacyjnym. W swoich rozważaniach będę czerpać z doświadczenia osobistego: podczas badań doktorskich prowadzonych w latach 2008-2010 byłam zaangażowana $\mathrm{w}$ prace nad projektami animacji kultury realizowanymi na obszarach wiejskich Polski centralnej.
\end{abstract}

\section{SŁOWA KLUCZOWE:}

sztuka wśród społeczności lokalnych, animacja kultury, antropologia sztuki, antropologia rozwoju, osoba, nauka rzemiosła, polityka kulturalna, etnografia 


\section{INTRODUCTION}

The question of whether a concept of society is "theoretically obsolete" or not was an important issue for the late $20^{\text {th }}$ century anthropologists ${ }^{2}$. The concept of society became an object of critique and theoretical consideration in the $1980 \mathrm{~s}^{3}$ simultaneously with the turn made by "Writing Culture" ${ }^{4}$. The issue for contemporary anthropologists was to rethink connections between parts and wholes in postmodern - and presumably post-holistic - realities ${ }^{5}$.

In order to recall the foundation idea of society, let us refer to Émile Durkheim. Durkheim believed that social structure works as a matrix - it shapes the lives of individuals but cannot be reduced to a sum of individual actions nor identified with them ${ }^{6}$. In "Suicide" the author introduced the first "individual - society" model with its ontological distinction between the social realm and individual realm ${ }^{7}$. When defining a social fact, the author claimed that it is "any way of acting, whether fixed or not, capable of exerting over the individual constraint; or which is general over the whole of a given society whilst having an individual existence of its own, independent of its individual manifestations"8. Thus, Durkheim made the first attempt in understanding the complex relationship between parts and wholes in social science. For him, social fact was obviously more than just a part and society was more than the collection of individuals as put all together.

For modern anthropologists, such as Malinowski and Radcliffe-Brown, society worked as a system of subordinated parts complementing one another. And whether it was the functionalist "whole" resembling a biological organism,

${ }^{2}$ T. Ingold (Ed.), Key debates in anthropology, New York: Routledge, 1996.

${ }^{3} \mathrm{M}$. Strathern, Parts and wholes: refiguring relationships in a post-plural world. In A. Kuper (Ed.) Conceptualizing society, London, New York: Routledge, 1992, pp. 75-104; N. Bubandt, T. Otto, Anthropology and the Predicaments of Holism. In N. Bubandt \& T. Otto (Eds.), Experiments in Holism. Theory and Practice in Contemporary Anthropology, Oxford: Willey-Blackwell, 2010, pp. 1-15.

${ }^{4}$ J. Clifford, G. E. Marcus (Eds), Writing culture: the poetics and politics of ethnography, Berkley: University of California Press, 1986.

${ }^{5}$ N. Bubandt, T. Otto, Anthropology and the Predicaments of Holism... op. cit., p. 1.

${ }^{6}$ É. Durkheim, The rules of sociological method, and selected texts on sociology and its method. In S. Lukes (Ed.), London and Basingstone: The Macmillan Press Limited, 1982.

${ }^{7}$ É. Durkheim, Suicide: a study in sociology, London: Routledge \& Kegan Paul, 1970.

${ }^{8}$ É. Durkheim, The rules of sociological method, and selected texts on sociology and its method... op. cit., p. 59. 
as described by Malinowski, or the structuralist "whole" network of relationships, as described by Radcliffe-Brown, the Durkheimian idea of society as an average for a given time and place seemed to be applied unchangeably ${ }^{9}$. As recounted by Marilyn Strathern, "The whole was known by its internal coherence, and thus its closure"10.

Finally, as an effect of the postmodern turn with its preference for fragmentation and the proclaimed death of grand narrative ${ }^{11}$, the existence of the "whole" understood as society, system and culture became an object of inquiry. Contemporary, academic styles of classification were put into question. Presenting relationships between parts and wholes in terms of fixed and stable dual oppositions, such as the nature and culture, or structure and agency, no longer seemed to be acceptable without methodological doubts ${ }^{12}$. Now, the question was, how to describe the relationships between individual and society in more dynamic terms. There was an obvious need for inventing a new metaphor ${ }^{13}$.

When rethinking holism, anthropologists focused on relationship between society and individual. It was because of the fact that "Western individualism and holism were born as a conceptual pair"14. What is more, societies, treated as fixed, internally bind and unique wholes, also seemed to be treated as "individual" systems - in comparison to one another. It was Radcliffe-Brown who first introduced such comparison as an analytical tool for British social anthropology ${ }^{15}$. According to Bubandt and Otto, this kind of assumption, however, had obviously something to do with the modern tendency to identify society with the nation and nation with the state. What was also taken into account in the discussions of the 1980s,

${ }^{9}$ G. E. Marcus, Holism and the Expectations of Critique in Post-1980s Anthropology: Notes and Queries in Three Acts and Epilogue. In N. Bubandt \& T. Otto (Eds.), Experiments in Holism. Theory and Practice in Contemporary Anthropology, Oxford: Willey-Blackwell, 2010, pp. 28-46.

${ }^{10}$ M. Strathern, Parts and wholes: refiguring relationships in a post-plural world... op. cit., p. 80.

${ }^{11}$ F. Lyotard, The Postmodern Condition, Manchester University Press, 1984.

${ }^{12} \mathrm{R}$. Wagner, The Invention of Culture (Revised and expanded edition), Chicago: University of Chicago Press 1981; M. Strathern, Parts and wholes: refiguring relationships in a postplural world... op. cit.

${ }^{13}$ Ibidem, p. 31.

${ }^{14}$ N. Bubandt, T. Otto, Anthropology and the Predicaments of Holism... op. cit., p. 10.

${ }^{15}$ A. R. Radcliffe-Brown, The comparative method in social anthropology, "The journal of the Royal Anthropological Institute of Great Britain and Ireland", 81(1-2)/1951, pp. 15-22; see also: M. Strathern Parts and wholes: refiguring relationships in a post-plural world... op. cit. 
was the relationship between the society and the state. The reflection was obviously influenced by the current political situation - the situation summed up by a famous slogan of Margaret Thatcher which denied the social in favor of the individuals and families. Anthropologists did oppose the assumption, claiming that the collapse of the communist system in Eastern Europe, which they witnessed, was done in the name of society and not in the name of individuals, families or state ${ }^{16}$.

The most crucial thing for anthropology was, however, a deep re-investigation and careful revision of bonds and boundaries between individual and society as addressed by Strathern. The question posed was, whether an 'individual' as such is still an adequate category ${ }^{17}$.

\section{RESEARCH METHODS}

\subsection{Crafing the 'self' through the process of apprenticeship: theoretical framework}

In the light of these discussions we can see Michael Herzfeld's concept of social poetics as an attempt to rethink the troubled dualism of structure and agency ${ }^{18}$. Michael Herzfeld discussed the concept of personhood in his book examining the character of the relationship between Cretan artisans and their apprentices ${ }^{19}$. He argued that what is being crafted there, through the process of apprenticeship, is not just artisanal skills, but most of all, a certain model of 'self'. Thus the process of apprenticeship is itself a mode of socialization that aims to craft a 'personhood' of a Cretan, male artisan. The 'self' of a Cretan artisan is being crafted in relation to his mastoras. What is important here is that apprentices are usually not agnatic kin. Mastoras usually call their apprentices 'foster sons'. However, their relationship with the mastoras does not resemble their relationship with fathers or uncles.

${ }^{16}$ See: T. Ingold (Ed.), Key debates in anthropology... op. cit.

${ }^{17}$ W. Plińska, Sprawczość sztuki. Kraków: Wydawnictwo Naukowe Uniwersytetu Pedagogicznego im. KEN w Krakowie, 2021, pp. 64-65.

${ }^{18}$ M. Herzfeld, Cultural Intimacy: Social Poetics in the Nation-State, New York and London: Routledge, 2005.

${ }^{19}$ M. Herzfeld, The Body Impolitic. Artisans and Artifice in the Global Hierarchy of Value, Chicago and London: The University of Chicago Press, 2004. 
According to Herzfeld, Cretan artisans learn their skills through the process of 'stealing it with the eyes' - mastores avoid explaining their craft, all skills can be therefore transferred only through the process of observation. Artisans also learn through the process of 'cunning' - an apprentice cannot let the masteros know how much he likes learning his craft, as this could only cause hostility towards him. Artisans also learn their craft in silence - it is crucial for them to keep the secrets of their craft unrevealed and also to remain restrained about revealing the secrets of their customers. As Herzfeld argued, in the world where gossip can ruin a life of an individual, those skills are crucial to the process of socialization. As a result, those apprentices who proved to be as 'aggressively competitive' as their masters, and who learned their craft through the process of 'stealing' and 'cunning' become respectable artisans. However, as soon as they achieve this goal, it also becomes clear that they will have difficulties with accessing another social environment. The main obstacle would be their newly learnt skills and 'bad' habits developed through the process of apprenticeship. What remains crucial for Herzfeld's concept is the idea that through the process of education, not only working-class values are being reproduced, as it was previously discussed by Paul Willis in his book "Learning To Labor: How Working-Class Kids Get Working Class Jobs" (1977), but also a certain reflection of self emerges through its performances. That reflection of self is not determinant, it is something that an individual can later play with. This suggests, still, that what is being crafted here is also a certain model of entering social relations and a certain model of relations between those relationships ${ }^{20}$.

\subsection{Research question}

During my ethnographic fieldwork, based on participant observation and informal interviewing, I was interested in the character of relations that are established through the process of managing a community art ${ }^{21}$ project. The question was, therefore, what model of 'self' is being crafted through participation in an artistic process. I mostly focused on the relational aspect of the art process, as I consider community art as an art that aims not as much to transform the materials

${ }^{20}$ W. Plińska, Sprawczość sztuki... op. cit., p. 29.

${ }^{21}$ C. Crehan, Community Art: An Anthropological Perspective, Oxford, New York: Berg Publishers, 2011. 
as to transform social relations ${ }^{22}$. I would therefore argue that community art is a kind of art that works on relations, as it was put by Nicolas Bourriaud who uses the notion of relational aesthetics to talk about the recent developments in $\operatorname{art}^{23}$. Relational art aims to transform the existing hierarchies, such as the hierarchy of taste. It also aims to have a political impact. Community artists are not so much focused on producing art works. Those artists, as I would argue, actually aim to transmit social values through the fact of one's participation in a project, which suggests that they also aim to craft a certain model of 'self' - both of an artist and of a participant. The participation in an art event (uczestnictwo) in the context of community art projects is usually described as a mode of 'creative collaboration' (twórcza wspótpraca). However, as suggested by Claire Bishop the ways in which contemporary art projects are evaluated these days usually corresponds to the level of engagement of its participants (e.g. a number of people involved is sometimes taken into account when assessing the value of an art event). To some extent, the notion of participation can be therefore understood here as an euphemism for labor ${ }^{24}$.

\subsection{Subject characteristics}

In 2008 I coordinated a community art project called "The Common Place" run with a group of my colleagues, young graduates of Section for Cultural Animation from the Institute of Polish Culture, University of Warsaw. 'Cultural animation' is a Polish tradition of community art inspired by Polish counterculture (to animate - to enliven, to inspire). It was initially born as a grassroots initiative, later brought to the academy at the beginning of the 1990s by art practitioners, intellectuals and academic professors. According to Andrzej Mencwel, community artists inherited the ethos of the modern Polish intelligentsia, educated middle class, with their affirmation for self-organization and community work. As recounted by the author: "Our idea of culture animation is based on the vision of cultural personality realized actively in the immediate human environment. That is a slightly utopian sentence and is thus exposed to the nowcommon

${ }^{22}$ A. Gell, Art and Agency. An Anthropological Theory, Oxford: Clarendon Press, 1998.

${ }^{23}$ N. Bourriaud, Estetyka relacyjna, Kraków: MOCAK, 2012, translated by Ł. Białkowski.

${ }^{24}$ C. Bishop, Artificial Hells: Participatory Art and the Politics of Spectatorship, London, Brooklyn NY: Verso, 2012, pp. 11-18. 
condemnation. However, I have nothing against utopia provided it has spontaneous sources and a human dimension"25.

It is important to emphasize that community artists were also strongly inspired by the work of Jerzy Grotowski and his Wrocław Laboratory Theatre. In the late 1960s Grotowski was already a world-famous theatre director, when he staged his last performance "Apocalypsis cum figuris". According to Leszek Kolankiewicz, the performance had an incredible effect on the audience, "as if it were not a theatre"26. After staging the performance, Grotowski announced that he is no longer interested in creating shows. Instead, he published an appeal to the youth called „A Proposal of Cooperation” and „invited those aiming to uncover themselves and encounter another man through movement and in freedom, to join the Laboratory Theatre"27. The next period of his work began with a series of workshops organized in Poland and abroad offering participatory, "paratheatrical" traineeship for a growing number of people. The total number of participants reached four and half thousands. Grotowski's movement towards "leaving the theatre behind" was rebellious also in artistic terms: his aim was to find a new form of art that breaks from the traditional dichotomies between the actor and the audience. From this point of view, there was actually no audience, nor spectators, but acts of mutually shared creativity. The reason was that the notion of creativity itself he understood not only as a privilege of the few, but as an attribute of all human beings. As recounted by Kolankiewicz, Grotowski wished to extend the sphere of what he called 'active culture' by creating „a kind of personal creative experience, which is not indiferrent for the life of an individual person, or his life with others"28.

The interest in local, 'indigenous' communities with their 'folk traditions', roots and origins also played a part in creating the 'alternative'. As Rolf Lindner put it, following Orvar Löfgren's thesis on the "nationalization of global developments", the alternative was a new usage of the cultural symbolism of countercultural

${ }^{25}$ A. Mencwel, A Leisurely Contribution. In P. Trompiz, G. Godlewski, L. Kolankiewicz (Eds.), Culture Animation: Looking Back and Forward, Warsaw: Institute of Polish Culture, 2002, p. 16.

${ }^{26}$ L. Kolankiewicz, Active Culture: The Primeval Times of Cultural Animation. In P. Trompiz, G. Godlewski, L. Kolankiewicz (Eds.), Culture Animation: Looking Back and Forward, Warsaw: Institute of Polish Culture, 2002, p. 24.

${ }^{27}$ Ibidem, p. 28.

${ }^{28}$ Ibidem, p. 36. 
movements "appropriated to the particular, national conditions"29. Following this approach, Polish countercultural movement was also a form of "imagined exclusion" from communist society. It aimed to build a new inner cultural reality also in resistance against the cultural policy approved by the state.

\section{4 "Development" as a field of anthropological research}

The so-called "culture of the project" came to Poland first at the beginning of the 1990s through international aid development projects (US funds, EU grants), and it was soon adopted by the state and non-governmental institutions ${ }^{30}$. Thus, in case of community artists, creativity started to mean also: dealing with the founders and learning how to speak in their professional language (Ministry of Culture, Ministry of Labor, EU Commission, National Centre for Culture, and many others). In other words, it meant also shaping their projects by using some crucial terms that were required, but with respect to personal values of the project creators. The procedure of shaping the project became somewhat similar to that used by development agencies ${ }^{31}$. According to Arturo Escobar, planning was therein a systematic process composed of fixed stages: problem identification, identification and assessment of alternatives, policy formulation, implementation and evaluation $^{32}$. Similarly, in the case of culture animation projects it was a "problem identification", "activities undertaken to resolve it", "predictable results" and "evaluation". The final shape of the project was therefore an issue of renegotiation, as public institutions seemed to take some control over the "meanings" shared by "professional communities". This way of formulating projects might cause "identifying people as a problem", as Escobar wrote. Community artists, supported by

${ }^{29}$ R. Lindner, The Construction of Authenticity: The Case of Subcultures. In J. Liep (Ed.), Locating Cultural Creativity, London: Pluto Press, 2001, p. 88.

${ }^{30}$ I. Iłowiecka-Tańska, Liderzy i działacze. O idei trzeciego sektora w Polsce, Warsaw: University of Warsaw Press, 2012.

${ }^{31} \mathrm{~A}$. Escobar, Anthropology and the development encounter: the making and marketing of development anthropology, "American Ethnologist", 18(4)/1991, pp. 658-682; D. Mosse, Anti-social anthropology? Objectivity, objection and the ethnography of public policy and professional communities... op. cit.; J. Ferguson Anthropology and Its Evil Twin. "Development" in the Constitution of a Discipline. In F. Cooper, R. Packard (Eds.), International Development and The Social Sciences. Essays on the History and Politics of Knowledge, Berkley: University of California Press, 1997, pp. 150-175.

${ }^{32}$ A. Escobar, Anthropology and the development encounter: the making and marketing of development anthropology... op. cit., p. 667. 
the state or EU grants, are still "local" actors, coming from their "local" centre, most of all, to support "necessary" social changes in "peripheral" communities ${ }^{33}$. It should take place through the collaborative art work and cooperation set up in the name of the "common good".

Ostałówek, the village where we worked in central Poland in 2008 was before subject to a long-term ethnographic fieldwork conducted by Tomasz Rakowski. The fieldwork was based on short study trips to the field which aimed to make students familiar with various cultural phenomena of what was called 'survival strategies' of village communities affected by the darker side of the Polish political transformation: closing down of work-places, the abolition of centrallyregulated small-farm system and unprofitability of most agricultural activities ${ }^{34}$. Nevertheless, this underprivileged region had very strong farming traditions and ethics, where most farmers owned small, individual farms very often kept only for their own needs. In the past local farmers used to work not only on the farms, selling products to the state purchase of agricultural produce, but also part-time in the nearest cities (men usually as plumbers, electricians, or labourers in state factories). Most of these workplaces were shut down in the 1990s. I was also visiting the site and doing research there from 2005 to 2008, before I made the decision to work on a community art project at the village. The rest of the project team was also familiar with the environment - all of them participated in 'ethnographic workshops' before.

\subsection{Crafting 'the self' through managing a community art project: notes from the field}

When we decided to work on the project, it took us over six months before we prepared the final version of it. We spent over six months on meetings (usually once a week) in a friendly coffeehouse. We therefore dedicated a lot of time to talking the idea through. At that stage, I was not very familiar with the procedure of planning a community art project, so I mostly learned it from my colleagues, on a peer-to-peer basis. What struck me in those preparations was that, as it was

${ }^{33}$ W. Plińska, T. Rakowski, Badanie - rozumienie - działanie społeczne. Projekt etnografii animacyjnej i etnograficznie zorientowanej animacji kultury, „Kultura Współczesna”, 4/2009, p. 33.

${ }^{34}$ T. Rakowski, Łowcy, zbieracze, praktycy niemocy. Etnografia człowieka zdegradowanego, Gdańsk: Słowo/obraz terytoria, 2009. 
suggested by my colleagues, our project was supposed to present itself as coherent and therefore both the schedule of activities and the idea behind it, needed to be confirmed each time when we spoke about it, literally on every meeting. That was also why it took us so much time to prepare the schedule of activities. What we struggled with most was also how to fit the project into the framework provided by different grant givers. We were not very experienced at that time, so we randomly chose the Ministry of Labor, which uses the EU Social Fund, to apply for support, as the place where the project was about to be run had a very huge rate of unemployment. It was therefore easy to identify it as a 'troubled zone' that needed aid and a 'boost' of 'activation'. In the end, the Ministry refused to honor us with a grant, but the University decided to give us some funding. After all, in 2008, we organized a small set of workshops and a couple of events that were to initiate a long-term engagement in the village, based on art-related activities.

While working on the "Common Place" project we wanted to find a way to discover community centres, 'common places', those still existing in the village and those already closed down. Community centres, places important for the villagers, as we all agreed, were present not only in their memories of past "community work", but also in their sense of belonging to the place. Many community centre buildings (school, firehouse, health centre, chapel) were considered as belonging to the village community due to the fact that they were literally built by people. Our idea was to bring a touch of new life to those places ${ }^{35}$. We aimed at collecting some stories about the 'common places' and then try to re-tell them in cooperation with local kids, at the end making performance with professional storytellers and folk musicians from Warsaw. During the project we all stayed in a closed down school building which soon became a temporary 'culture house'. We chose the venue, although the building already required renovation, as I was offered to live there by local people. As they stated: "the school building should never stay empty!", "something should be definitely organised here: a summer school for kids, or a family fest!", "we built the school in the past - so it belongs to the community!". However, when I was arranging the rental, the borough leader who administrated the building on behalf of the local government told me that the the venue was already looking for a new, private owner.

${ }^{35}$ Ibidem, p. 44. 
The workshops for kids - very much appreciated by their parents because during summer holidays kids usually have nothing to do - were organized in another 'common place' - the local firehouse. We also arranged a folk dance party in the same building for all the people, just like it used to take place in Polish villages in the past. In cooperation with local kids we did stage a performance based on storytelling. However, while working on the project what became most important for me was the everyday cooperation with villagers itself, especially with the village youth. They were not only visiting us at the school building, but also entertained us with a beautiful birthday party organized in the open field with burning bonfire where they improvised some hip-hop freestyle rhymes, somehow similar to traditional folk songs. The fact that we took part in spontaneous gatherings and parties organized by the youth seemed to encourage them and give space for "shared creativity". According to John Liep, "creativity involves the bridging of gaps through the fusion of disparate cultural configuration" and at that point could be understood as an interaction "involving different values, world views and forms of expression" ${ }^{36}$. According to him, only this can lead to social change ${ }^{37}$.

\subsection{Ethnography as a mode of probing the boundaries of the project}

We wanted to continue the project as soon as we get more funding, but I was not invited to take part in its continuation. The moment when I was excluded from the project was the crucial moment when my understanding of community art projects actually started to grow. It is worth emphasizing that I had a chance to work with some of my colleagues afterwards. Not long after I left the project, we did a couple of small events together, but we never did work together in the same village again. I would therefore argue that the fact that I was expelled from the project had much more to do with the failure of a certain model of cooperation that was aimed to craft my 'self' as a future community artist. It is not possible to investigate on such phenomena without the assumption that what was really crafted there was a set of relationships: first, the relationship between some young, middle-class, educated artists, as a team; secondly, the relationship

${ }^{36}$ J. Liep, Introduction. In J. Liep (Ed.) Locating Cultural Creativity, London: Pluto Press, 2001, p. 12.

${ }^{37}$ W. Plińska, T. Rakowski, Badanie - rozumienie - działanie społeczne. Projekt etnografii animacyjnej i etnograficznie zorientowanej animacji kultury... op. cit., p. 49. 
of activists with the 'local community'. The desire to influence also the relationships between people in the village was actually, as I noticed, the last stage of that process.

How was that supposed to be achieved? What I realized when working in the project was that because it requires working in a team, the project coordinators first need to build strong ties between themselves, in order to be able to cooperate with the community. Community art projects are usually a set of events, therefore what is transmitted there is also an assumption that some modes of cooperation are more valuable, and some are less. We therefore encounter 'a global hierarchy of value' ${ }^{38}$ already when devising the project. The model of 'self' projected here is a self that can enter relationships based on cooperation set up in the name of the 'common good'. But what is that suppose to mean?

The topic of my research was focused on investigating the situation of 'creating a project': by discussing it, constructing it and finally by cooperating in the process of its making. I regarded my position in the community of professionals as not very powerful. I was drifting somewhere between the position of an 'accepted' and 'unaccepted' ignoramus. It was a position of someone, who stays near the project community and who sometimes can be of use, but who generally still does not quite know "what is community art all about". I was a 'collaborator' I had my own vision, my own doubts, which I shared with the others. I also argued with them. For the purpose of fieldwork, one usually needs to enter some social environment, but how can one enter the environment which she not only investigates, but also co-creates? From the very beginning, I was deeply concerned with how to present my own collaboration and engagement in the field. What was going on in the projects was never indifferent to me. I wanted to have an influence on what we were doing. I also believed in community art as an attractive tool for engaging with people. As a result, I was excluded from the project work not long after I shared some of my doubts with the team I worked with. I would present those uncertainties as a set of questions: how did it happen that community artists, who graduated from an anthropologically oriented department are at the same time so prone to identify themselves with 'the language of the project'? Why people who approach local communities in such a skillful way using their artistic

${ }^{38}$ M. Herzfeld, The Body Impolitic. Artisans and Artifice in the Global Hierarchy of Value... op. cit. 
and sociological imagination need to use a language which does not describe the results of their own expertise?

Observing how the project worked, I posed more on more question on how things were done. Why someone who observed that the most creative group in the village is a group of teenage boys decides to work with teenage girls instead, as 'they would agree' on the mode of cooperation proposed by the artist? Why professionals who were trained in using their ethnographic imagination plan to organize a set of training workshops for 'local participants', who they previously recognized as 'creative'? Why the workshops dedicated to 'local participants' needed to end with a training on how to write your own project proposal? I was struck by the fact that in the documents, such as the project proposal, they put statements such as 'the project will push the local community to cooperate more efficiently'. I also did not like the fact that the continuation of our project needed to be divided into three projects run in three different villages, where participants were trained in 'soft skills', 'integrated' and later 'taught' how to work in a team. Each of the teams was supposed to organize a small project in their own village and invite others to watch the final effect and participate. That was also why the biggest organizational problem and the most expensive part of the project was logistics. It is a paradox to me, that the same people who seemed so close to me when worked together in the village, became so distant when we discussed the 'project planning'.

\section{ON ETHNOGRAPHY OF CULTURAL POLICY AND`PROFESSIONAL COMMUNITIES'}

Here, I would propose two arguments drawn from two perspectives. One would require looking at the community art project as an element of the cultural policy of the nation state and also as an effect of the cultural policy of the Eropean Union. The people I worked with, where trained in such projects as "Animator" and "Leonardo da Vinci" which are a part of the EU policy. The second perspective would require to perceive those cultural activists as artists. Even though they do not necessarily call themselves artists, there is no doubt that all of them act with great artistic sensitivity. The EU training is crucial for understanding the way the projects operate. The community artists I worked with were trained as a result of EU projects aimed at educating young Poles in order to give them more opportunities 
in the job market. As a result, a group of well-educated professionals - cultural activists and community artists - has emerged. These people knew how to conduct an art-related workshop, they collected work experiences, including both participation and cooperation in various national and international projects. The activists treated their tasks with great responsibility and they were ready to negotiate their fees with the project coordinator. They were also willing to solve any problems that occur during the project by getting more training and supervision. They were also ready to cooperate with other professionals and to seek support from those whom they perceived as experts in the field. I remember one conversation we had when we realized that we actually are able to understand each others' doubts because we share similar uncertainties with regard to our relations with the community. However, my colleagues decided, that they would still submit the project to the Ministry of Culture, because it was important to them. I myself saw it as only a set of workshops designed for village participants by city activists.

As a result, I realized that community artists have always acted in a weaker or stronger relationship with the document of the project proposal itself (wniosek). The proposals were prepared for the purpose of applying for funding, but that was not the only goal. The final shape of the project proposal was always an effect of negotiation - between the grant-giver and project coordinators, and also between the team itself and particular individuals. As I observed, the project proposal was the document that secured the project's finances. Moreover, in case of young activists, it also secured their own wages. Thus, as I observed, the project proposal was not only 'a measure' put in place to gain some money 'to make the ideas reality', as community artists usually explained it to me. The project proposal was also a part of the discourse that framed the actions of the team members. The proposal was therefore not an 'additional' element, but a part of what was really important for the activists - that is their actions. It is worth emphasizing that community artists themselves were educated as a result of submitting another project proposal - the one that enabled the Institute of Polish Culture to support them from EU grants. Even though the activists themselves usually stressed that they 'do not fully identify themselves with the language of the project' (that is 'with the language of the grant-givers') and often presented the project proposal as something different from their actions, these two realms actually merged with each other.

On the other hand, the notion of being an artist, born on the Western definitions of modern art, requires him/her to be an individual, who cultivates freedom, 
creativity and ingenuity of his own ideas. The attitude was, in my opinion, possible to be observed during our discussions, when we were 'brain storming' or when we were arguing. Any sort of critique was not welcome in our team and it was always treated very harshly, as a threat to the project itself. Community artists craft their 'selves' through the process of leading a project, so if the project is undermined, it also undermines their identification as community artists. As I would argue, the role of the artist did not dominate over the role of the 'team member.' All activities concerning the project were always performed in a team, until the 'collective interpretation' emerged ${ }^{39}$. If I decided to deny the 'collective interpretation', it meant that 'I did not understand it'. Whenever I shared some of my doubts with my colleagues - e.g. on whether we should really organize a set of training workshops in order to recruit the 'local activists-to be' - I was doing it on purpose. I wanted to probe the boundaries of the discourse. What I heard was usually: „Yes, but that is not what this is all about", "This is not what we mean”, "You do not seem to understand". It remains clear therefore that my colleagues shared a kind of 'professional intimacy' and I was threatening it by revealing its internal inconsistencies.

\section{CONCLUSION}

To sum up, in the article I tried to look at the process of socialization of Polish community artists, somewhat resembling the process of artisanal training. I would like to point out that for community artists 'crafting the self' takes place through the process of forming relationships: with the team and with the local community but also with the written project proposal. Only the nexus of these relationships allows one to understand the process of becoming a community artist. It is worth emphasizing that, according to John Liep, "the connection between the growth of creativity and the processes associated with modernity seem clear" although what we associate with Western modernism "does not penetrate with the same force, or establish itself in identical configuration globally"40. As I tried to show in

${ }^{39}$ D. Mosse, Anti-social anthropology? Objectivity, objection and the ethnography of public policy and professional communities... op. cit.

${ }^{40}$ J. Liep, Introduction. In J. Liep (Ed.) Locating Cultural Creativity, London: Pluto Press, 2001, p. 3. 
my article, the 'global hierarchy of value' can be also seen in the process of managing a community art project.

\section{REFERENCES}

C. Bishop, Artificial Hells: Participatory Art and the Politics of Spectatorship, London, Brooklyn NY: Verso, 2012.

N. Bourriaud, Estetyka relacyjna, translated by Ł. Białkowski, Kraków: MOCAK, 2012.

N. Bubandt, T. Otto, Anthropology and the Predicaments of Holism. In N. Bubandt \& T. Otto (Eds.), Experiments in Holism. Theory and Practice in Contemporary Anthropology, Oxford: Willey-Blackwell, 2010, pp. 1-15.

J. Clifford, G. E. Marcus (Eds), Writing culture: the poetics and politics of ethnography, Berkley: University of California Press, 1986.

C. Crehan, Community Art: An Anthropological Perspective, Oxford, New York: Berg Publishers, 2011.

É. Durkheim, The rules of sociological method, and selected texts on sociology and its method. In S. Lukes (Ed.), London and Basingstone: The Macmillan Press Limited, 1982.

É. Durkheim, Suicide: a study in sociology, London: Routledge \& Kegan Paul, 1970.

A. Escobar, Anthropology and the development encounter: the making and marketing of development anthropology , „American Ethnologist”, 18(4)/1991, pp. 658-682.

J. Ferguson, Anthropology and Its Evil Twin. "Development" in the Constitution of a Discipline. In F. Cooper, R. Packard (Eds.), International Development and The Social Sciences. Essays on the History and Politics of Knowledge, Berkley: University of California Press, 1997, pp. 150-175.

A. Gell, Art and Agency. An Anthropological Theory, Oxford: Clarendon Press, 1998.

M. Herzfeld, Cultural Intimacy: Social Poetics in the Nation-State, New York and London: Routledge, 2005.

M. Herzfeld, The Body Impolitic. Artisans and Artifice in the Global Hierarchy of Value, Chicago and London: The University of Chicago Press, 2004.

I. Iłowiecka-Tańska, Liderzy i działacze. O idei trzeciego sektora w Polsce, Warsaw: University of Warsaw Press, 2012.

T. Ingold (Ed.), Key debates in anthropology, New York: Routledge, 1996.

L. Kolankiewicz, Active Culture: The Primeval Times of Cultural Animation. In P. Trompiz, G. Godlewski, L. Kolankiewicz (Eds.), Culture Animation: Looking Back and Forward, Warsaw: Institute of Polish Culture, 2002, pp. 20-49.

R. Lindner, The Construction of Authenticity: The Case of Subcultures. In J. Liep (Ed.) Locating Cultural Creativity, London: Pluto Press, 2001, pp. 81-89.

J. Liep, Introduction. In J. Liep (Ed.) Locating Cultural Creativity, London: Pluto Press, 2001, pp. 1-13.

F. Lyotard, The Postmodern Condition, Manchester University Press, 1984. 
A. Mencwel, A Leisurely Contribution. In P. Trompiz, G. Godlewski, L. Kolankiewicz (Eds.), Culture Animation: Looking Back and Forward, Warsaw: Institute of Polish Culture, 2002, pp. 13-19.

G. E. Marcus, Holism and the Expectations of Critique in Post-1980s Anthropology: Notes and Queries in Three Acts and Epilogue. In N. Bubandt \& T. Otto (Eds.). Experiments in Holism. Theory and Practice in Contemporary Anthropology, Oxford: Willey-Blackwell, 2010, pp. 28-46.

W. Plińska, Sprawczość sztuki. Kraków: Wydawnictwo Naukowe Uniwersytetu Pedagogicznego im. KEN w Krakowie, 2021.

W. Plińska, T. Rakowski, Badanie - rozumienie - działanie społeczne. Projekt etnografii animacyjnej i etnograficznie zorientowanej animacji kultury, „Kultura Współczesna”, 4/2009, pp. 32-50.

A. R. Radcliffe-Brown, The comparative method in social anthropology, "The journal of the Royal Anthropological Institute of Great Britain and Ireland", 81(1-2)/1951, pp. 15-22.

A. R. Radcliffe-Brown, Structure and function in primitive society: essays and addresses by A. R. Radcliffe-Brown, Glencoe, Illinois: The Free Press, 1952.

T. Rakowski, Łowcy, zbieracze, praktycy niemocy. Etnografia człowieka zdegradowanego. Gdańsk: Słowo/obraz terytoria, 2009.

M. Strathern, Parts and wholes: refiguring relationships in a post-plural world, In A. Kuper (Ed.) Conceptualizing society, London, New York: Routledge, 1992, pp. 75-104.

M. Strathern, Partial connections (updated edition), Walnut Creek: AltaMira Press, 2004.

R. Wagner, The Invention of Culture (Revised and expanded edition), Chicago: University of Chicago Press, 1981.

P. Willis, Learning to Labor: How Working Class Kids Get Working Class Jobs, New York: Columbia University Press, 1977.

\section{Biogram}

Weronika Plińska - born in 1983. Cultural anthropologist. Assistant Professor at the Faculty of Art, Pedagogical University of Cracow. In 2017 I defended my PhD thesis entitled Animating Local Communities Through Artistic Practices: an Anthropological Perspective at the University of Warsaw. Between 2015 and 2017 I was lecturing at the Institute of Ethnology and Cultural Anthropology, UW. In 2010/2011 I did affiliate studies at University College London Department of Anthropology and School of Slavonic and East European Studies. In addition to numerous articles, I have authored the book: Sprawczość sztuki (The Agency of Art, 2021).

ORCID: 0000-0001-5469-793X 